\title{
HUBUNGAN HUKUM ANTARA BANK DENGAN AGEN LAKU PANDAI (BRANCHLESS BANKING) DALAM PELAKSANAAN PERANTARA KEUANGAN (FINANCIAL INTERMEDIARY) DIHUBUNGKAN DENGAN PRINSIP KEPERCAYAAN (FIDUCIARY PRINCIPLE)
}

\author{
Priadhi Harry Ramdhany \\ Alumni Program Studi Magister Ilmu Hukum Pascasarjana UNISBA \\ E-mail: phramdhany182@gmail.com
}

\begin{abstract}
ABSTRAK
Bank sebagai lembaga intermediari keuangan belum bisa diakses oleh semua kalangan masyarakat terutama masyarakat di perdesaan, baru sekitar 52\% masyarakat yang bisa mengakses dari seluruh populasi penduduk Indonesia. Banyak faktor yang menyebabkan rendahnya akses masyarakat terhadap perbankan salah satunya yakni jauhnya jarak kantor cabang dengan lokasi tempat tinggal. Untuk mengatasi hal tersebut bank membuat sebuah inovasi berupa layanan keuangan tanpa kantor (branchless banking) yang memberikan kemudahan akses, kepraktisan, kenyamanan dan biaya yang ekonomis terhadap produk yang ditawarkan kepada masyarakat melalui penggunaan sarana teknologi dan informasi tanpa harus datang atau melalui kantor fisik bank. Penelitian ini mengungkap mengenai hubungan hukum antara bank dengan agen laku pandai (branchless banking) dalam pelaksanaan perantara keuangan (financial intermediary). Penelitian ini menggunakan metode penelitian kualitatif dengan pendekatan yuridis normatif yaitu dengan cara meneliti bahan pustaka atau data sekunder. Hasil penelitian menunjukkan bahwa agen merupakan kepanjangan tangan dari bank yang menyelenggarakan layanan branchless banking untuk memberikan layanan keuangan pada masyarakat.
\end{abstract}

Kata Kunci : bank, branchless banking, financial intermediary, fiduciary principle.

\section{ABSTRACT}

Banks as financial intermediary institutions cannot be accessed by all segments of society, especially people in rural areas, only about 52\% of the population can access the entire population of Indonesia. Many factors cause low public access to banking, one of which is the distance from the branch office to the location of residence. To overcome this, banks create and innovation in the form of branchless banking that provides easy access, practicality, convenience and economical costs for products offered to the public through the use of technology and information facilities without having to come or through the office. bank physical. This study reveals the legal relationship between banks and branchless banking agents in implementing financial intermediaries. This study uses qualitative research methods with a normative juridical approach that is by examining library materials or secondary data. The results showed that the agent is an extension of the bank that provides branchless banking services to provide financial services to the public.

Keywords : bank, branchless banking, financial intermediary, fiduciary principle.

\section{A. PENDAHULUAN}

Sesuai dengan laju pertumbuhan ekonomi dan gerak suatu bangsa, dalam hal pengerahan dana, masyarakat tidak dapat mengesampingkan peranan lembaga perbankan oleh karena lembaga keuangan 
tumbuh dengan berbagai alternatif jasa yang ditawarkan. Bank sebagai lembaga yang bekerja berdasarkan kepercayaan masyarakat sesuai dengan fungsinya yaitu sebagai penghimpun dan penyalur dana masyarakat (financial intermediary). Sebagai lembaga perantara keuangan masyarakat (financial intermediary) bank menjadi media perantara pihak pihak yang memiliki kelebihan dana (surplus of funds) dengan pihak-pihak yang kekurangan dana (lack of funds). (NENI SRI IMANIYATI DAN PANJI ADAM AGUS PUTRA 2016:15).

Lembaga perbankan memiliki misi dan fungsi sebagai agen pembangunan (agent of development), yaitu sebagai lembaga yang bertujuan menunjang pelaksanaan pembangunan nasional dalam rangka meningkatkan pemerataan, pertumbuhan ekonomi, dan stabilitas nasional ke arah peningkatan kesejahteraan rakyat banyak. Hal tersebut dimaknai dalam Pasal 1 angka 1 UndangUndang No. 7 Tahun 1992 sebagaimana telah diubah dengan Undang-Undang No. 10 Tahun 1998 tentang Perbankan. Bahwa bank adalah badan usaha yang menghimpun dana dari masyarakat dalam bentuk simpanan dan menyalurkannya kepada masyarakat dalam bentuk kredit dan atau bentuk-bentuk lainnya dalam rangka meningkatkan taraf hidup rakyat
banyak.Bank sebagai penyedia layanan keuangan perbankan dalam pelaksanaan perantara keuangan (financial intermediary) bagi orang yang kelebihan dana (surplus of funds) ke orang yang kekurangan dana (lacks of fund) berdasarkan prinsip kepercayaan terhadap nasabah yang menyimpan uangnya untuk disalurkan melalui simpanan oleh Bank berupa layanan simpan-pinjam, kredit, Asuransi, deposito, Giro, saham, untuk perkembangan dan kemajuan usaha perdagangan. (USWATUN HASSANAH 2017:23).

Layanan perbankan diharapkan dapat diakses oleh semua kalangan masyarakat mulai dari pedesaan hingga masyarakat yang tinggal di kota, namun di Indonesia Layanan Keuangan dalam hal ini Bank tidak dapat diakses sebagian besar masyarakat. Sebagai contoh hanya $52 \%$ masyarakat Indonesia yang dapat mengakses layanan Bank dari jumlah total populasi. Faktor-faktor yang menyebabkan terhambatnya akses masyarakat terhadap sektor keuangan formal dikelompokkan menjadi dua kategori yaitu dari sisi permintaan dan dari sisi penawaran. Rendahnya akses masyarakat terhadap jasa keuangan, rendahnya pendapatan, tidak adanya jaminan sosial inklusif, jauhnya jarak cabang bank dengan tempat tinggal, prosedur yang rumit, ketidaksesuaian 
produk keuangan dengan kebutuhan, bahasa yang kurang dimengerti dan waktu operasi bank yang kaku. (RAKHMINDYARTO

DAN

SYAIFULLAH 2013:2).

Sebuah inovasi berhasil mentransformasi suatu sistem atau pasar yang eksisting, dengan memperkenalkan kepraktisan, kemudahan akses, kenyamanan, dan biaya yang ekonomis, dikenal sebagai inovasi Disruptif (Disruptive Innovation). Fenomena inovasi Disruptif juga terjadi di Industri Jasa Keuangan yang telah men-disrupsi landscape Industri Jasa Keuangan secara global. Mulai dari struktur industrinya, teknologi intermediasinya, hingga model pemasarannya kepada konsumen. Inovasi yang bersifat disruptif dapat dilihat pada layanan keuangan tanpa kantor (branchless banking) yang memberikan kemudahan akses, kepraktisan, kenyamanan dan biaya yang ekonomis terhadap produk yang ditawarkan kepada masyarakat yang belum mengenal, menggunakan, dan/atau mendapatkan layanan perbankan dan layanan keuangan lainnya melalui penggunaan sarana teknologi dan informasi tanpa harus datang atau melalui kantor fisik bank. (MULIAMAN D.HADAD 2017:3).
Pasal 1 Ayat 3 Peraturan Otoritas Jasa Keuangan No. 19/POJK/03/2014 Layanan Keuangan Tanpa Kantor Dalam Rangka Keuangan Inklusif yang selanjutnya disebut Laku Pandai adalah kegiatan menyediakan layanan perbankan dan/atau layanan keuangan lainnya yang dilakukan tidak melalui jaringan kantor, namun melalui kerja sama dengan pihak lain dan perlu didukung dengan penggunaan sarana teknologi informasi.

Bank dalam menyelenggarakan layanan keuangan tanpa kantor (branchless banking) bekerja sama dengan agen laku pandai tentunya wajib untuk memiliki perjanjian secara tertulis dengan agen laku pandai. Perjanjian merupakan suatu perikatan akibat dari peristiwa hukum dimana para pihak mengikatkan dirinya secara tertulis yang diatur dalam KUHPerdata. KUHPerdata mengatur mengenai kebebasan berkontrak bagi para pihak yang mengikatkan dirinya, syarat sahnya perjanjian, asas kepastian hukum (pacta sunt servanda), asas itikad baik (good faith), dan asas keperibadian (personality). (Pasal 22 Ayat 1 Huruf B Peraturan Otoritas Jasa Keuangan No. 19/POJK/03/2014 Layanan Keuangan Tanpa Kantor Dalam Rangka Keuangan Inklusif)

Berdasarkan latar belakang tersebut maka penulis akan mengkaji hubungan 
hukum antara bank dengan agen laku pandai (branchless banking) mengingat pelaksanaan fungsi bank sebagai penghimpun dan penyalur dana dari masyarakat serta adanya prinsip kepercayaan dalam hal pengumpulan dan penyimpanan dana masyarakat, maka menjadi perlu untuk melakukan penelitian sebagai upaya untuk memahami bagaimanakah hubungan hukum antara bank dan agen laku pandai (branchless banking) dalam pelaksanaan fungsi perantara keuangan (financial intermediary) dan tanggung jawab hukum bank jika agen laku pandai wanprestasi.

\section{B. PEMBAHASAN}

\section{Keuangan Inklusi Dan Sistem} Pembayaran Melalui Agen Dalam

\section{Pelaksanaan Perantara Keuangan}

Sistem pembayaran yang canggih adalah sistem yang mampu meningkatkan daya saing perekonomian nasional melalui peningkatan financial inclusion dalam masyarakatnya. Menurut ahli ekonomi Belanda J.H. Boeke dengan dualism perekonomiannya memperlihatkan akan adanya dua dimensi penting dalam perekonomian, yaitu sektor modern yang mendapatkan akses perbankan dan sektor tradisional yang belum tersentuh oleh akses perbankan. (NAOYUKI YOSHINO \& PETER J MORGAN 2017:25).
Keberadaan masyarakat merupakan faktor penting yang perlu dipertimbangkan oleh perbankan, oleh karena itu, jumlah kantor bank di suatu wilayah harus memperhatikan tingkat populasi dan kepadatan penduduk. Semakin banyak jumlah penduduk di suatu wilayah, maka semakin tinggi kebutuhan mereka terhadap jasa perbankan.

Fungsi utama bank adalah sebagai lembaga intermediasi, antara pihak yang kelebihan dana (supply unit) dengan pihak yang membutuhkan dana (demand unit). Dana yang diterima bank dapat disalurkan pada kegiatan-kegiatan produktif, menyerap tenaga kerja, meningkatkan output dan pada akhirnya menggerakkan siklus perekonomian. Oleh karena itu, pertumbuhan ekonomi suatu negara sangat memerlukan dukungan industri perbankan yang sehat dan efisien.

Bank Indonesia mengemban tugasnya sebagai bank sentral yang dapat berperan sebagai regulator sistemik pasca krisis global. Fungsi bank sentral tersebut; pertama, bank sentral sebagai jembatan langsung antara pelaku pasar untuk mengimpelementasikan kebijakan moneter sentral; kedua, Bank Indonesia memiliki tanggung jawab untuk menjamin stabilitas sistem keuangan dengan mempertahankan stabilitas ekonomi makro; ketiga Bank Indonesia memainkan fungsi "lender of 
last resort" yang akan sangat bermanfaat dalam penyediaan dana darurat jangka pendek di masa krisis. Sesuai dengan kesepakatan di KTT G-20 Washington, ditetapkan 12 agenda reformasi sektor keuangan global, sebagai berikut :

1. Penguatan rejim permodalan global dan standar likuiditas perbankan serta mitigasi procyclicality (Building high quality capital and liquality standards)

2. Reformasi skim kompensasi bagi eksekutif di lembaga keuangan

3. Penguatan pasar OTC derivatives markets

4. Pengaturan resolusi untuk lembaga keuangan yang berdampak sistemik

5. Penguatan kepatuhan terhadap standard internasional

6. Penguatan standar akuantansi

7. Pengembangan kerangka kebijakan makroprudensial

8. Harmonisasi regulasi pasar dan lembaga keuangan

9. Pengaturan Hedge Funds

10. Pengaturan lembaga pemeringkat (Credit Rating Agencies)

11. Pendirian Supervisory Colleges

12. Reaktivasi pasar sekuritasasi dengan landasan prudensial yang lebih kuat (Re-launching securitization and sound basis)
(ADRIANA

ELISABETH

2008:87)

"All inclusive financial banking system”, melalui peningkatan peran Bank Perkreditan Rakyat dalam pembiayaan keuangan mikro dan penguatan ketahanannya melalui pemberian insentif untuk mendorong peningkatan modal, memberikan fasilitas pemenuhan kebutuhan Sumber Daya Manusia BPR yang berkualitas dan kompeten serta penguatan terhadap posisi BPR sebagai community bank. Kebijakan dalam perbankan ini sangat penting sebagai strategi Indonesia untuk membuat lembaga perbankan dapat diakses oleh segala kalangan, termasuk kelompok marginal. Kelompok marginal-marginal ini selama ini mendapatkan pinjaman dari lembagalembaga informal seperti renternir yang seringkali merugikan kelompok tersebut, disamping lembaga perbankan nasional kesulitan untuk melakukan regulasi dan pengawasan terhadap agen-agen kredit informal tersebut. (YULIUS P HERMAWAN 2001:42)

Perdagangan bebas Intra ASEAN akan berlangsung pada tahun 2015 mendatang memberikan kesempatan bagi sektor perbankan nasional untuk menciptakan strategi pembangunan ekonomi nasional yang mampu meningkatkan daya saing perekonomian 
nasional dengan mengembangkan strategi perbankan nasional yang terintegrasi dengan pembangunan ekonomi tersebut. Salah satu strateginya adalah dengan mengembangkan branchless banking (perbankan tanpa cabang) melalui perkembangan teknologi bergerak dari perbankan tanpa cabang. Jika strategi ini di desain secara tepat dipastikan perbankan nasional bukan saja mampu memobilisasi dana terpendam di dalam negeri akibat rendahnya financial inclusion selama ini (ACHMAD DENI DARURI 2013:2)

Dalam Pasal 1 angka 4 Peraturan Otoritas Jasa Keuangan Nomor 19/POJK.03/2014 tentang Layanan Keuangan Tanpa Kantor Dalam Rangka Keuangan Inklusif memberikan keterangan mengenai kedudukan agen sebagai pihak yang bekerja sama dengan Bank penyelenggara Laku Pandai yang menjadi kepanjangan tangan Bank untuk menyediakan layanan perbankan kepada masyarakat dalam rangka keuangan inklusif sesuai yang diperjanjikan

Dengan adanya layanan keuangan tanpa kantor/Branchless Banking di wilayah pedesaan diharapkan tercapainya sasaran menuju keuangan inklusif (financial inclusion). Keuangan inklusif (financial inclusion) adalah seluruh upaya yang bertujuan meniadakan segala bentuk hambatan yang bersifat harga maupun non harga, terhadap akses masyarakat dalam memanfaatkan layanan jasa keuangan. Keuangan inklusif ini merupakan strategi nasional untuk mendorong pertumbuhan ekonomi melalui pemerataan pendapatan, pengentasan kemiskinan serta stabilitas sistem keuangan.

Dalam strategi Nasional keuangan inklusif, strategi keuangan inklusif dijabarkan dalam 6 pilar, yaitu; edukasi keuangan, fasilitas keuangan publik, pemetaan informasi keuangan, kebijakan/peraturan pendukung, fasilitas intermediasi dan distribusi, serta perlindungan konsumen. Untuk mewujudkan program keuangan inklusif yang berkesinambungan diperlukan koordinasi antara Bank Indonesia dengan kementrian dan insitusi terkait dalam rangka pengembangan, penetapan prioritas dan pelaksanaan program serta pelaksanaan monitoring dan evaluasi program yang diharapkan sesuai dengan tujuan utama yaitu meningkatkan akses layanan keuangan kepada masyarakat yang belum terakses terkait layanan keuangan dalam rangka pertumbuhan dan stabilitas ekonomi kearah yang lebih baik.

Disisi lain, sektor UMKM yang merupakan sektor yang terbukti tangguh dalam menghadapi krisis ekonomi kurang mendapat perhatian karena berbagai kendala. Sektor ini diperkirakan 
memberikan kontribusi sebesar 57,1\% terhadap pendapatan Domestik Bruto (PDB) dengan pangsa mencapai 99\% dari total unit usaha di Indonesia serta menyerap $97,2 \%$ dari total tenaga kerja. Ironisnya , pangsa kredit UMKM hanya $20 \%$ dari total kredit perbankan. Padahal tiga penelitian yang ada terkait UMKM mengungkapkan potensi pembiayaan perbankan untuk UMK masih cukup tinggi. Dengan menggunakan asumsi bahwa PDB sampai dengan tahun 2018 tumbuh 6,5\% dan potensi Usaha Mikro dan kecil di tahun 2018 diperkirakan mencapai Rp. 1.588,42 triliun. (PUNGKY PURNOMO WIBOWO)

Optimalisasi branchless banking merupakan perwujudan dari amanat tujuan nasional yang tercantum dalam Pembukaan UUD NKRI 1945 tersebut yakni memajukan kesejahteraan umum yang berdasarkan keadilan sosial. Selanjutnya pada Pasal 27 ayat (2) menegaskan bahwa tiap-tiap warga negara berhak atas pekerjaan dan penghidupan yang layak bagi kemanusiaan. Amanat Pasal 28 ayat (2) menegaskan bahwa setiap orang berhak mendapatkan kemudahan dan perlakuan khusus untuk memperoleh kesempatan dan manfaat yang sama guna mencapai persamaan dan keadilan, salah satu caranya adalah dengan berbank. Dengan demikian pelaksanaan branchless banking sesuai dengan dasar konstitusional.

\section{Analisa Hubungan Hukum Agen} Laku Pandai Dengan Nasabah Berdasarkan Perjanjian Menurut KUHPerdata

CST Kansil dan Christine ST Kansil menyampaikan tentang perusahaan yang memberikan jasa perantara yang terikat pada persetujuan tertentu atas nama dan untuk principalnya disebut agen perniagaan, sedangkan perusahaan dari agen perniagaan tersebut biasa disebut dengan agentuur sedangkan untuk persetujuan yang dibuat oleh agen perniagaan dan principalnya disebut dengan agentuur contract. Agen perniagaan yang bertugas sebagai perantara dapat mewakili beberapa perusahaan asalkan tidak boleh merugikan principalnya, karena ia bertindak atas nama pengusaha yang ia wakili, dan tidak atas nama diri sendiri serta agen berhak untuk memperoleh provisi dari principalnya. "Keberadaan agen tidak diatur dalam KUHD, tetapi banyak terdapat dalam praktik perniagaan seharihari. (CST KANSIL DAN CHRISTINE ST KANSIL 2002:42)

Hubungan hukum antara agen dan Bank Laku Pandai dalam kegiatan layanan perbankan branchlesss banking merupakan 
" suatu hubungan hukum di mana seseorang/ pihak agen diberi kuasa bertindak untuk dan atas nama orang/ pihak prinsipal untuk melaksanakan transaksi bisnis dengan pihak lain". Adanya kuasa dari orang/ principal maka tindakan-tindakan yang dilakukan agen dalam batas-batas yang sudah ditentukan oleh principal, tetapi apabila agen melakukan hal-hal diluar batas wewenangnya maka agen harus bertanggung jawab atas tindakannya. (RICHARD BURTON SIMATUPANG 2003:53)

Perorangan atau badan hukum yang berkeinginan menjadi agen laku pandai harus melalui beberapa penilaian/ fit and propertest. Pentingnya keberadaan agen dalam menunjang layanan branchless banking, maka Antara Bank Penyelenggara Laku Pandai dan agen terdapat kerjasama tertulis, yang berisi halhal yang termuat dalam pasal 22 ayat (22) Peraturan Otoritas Jasa Keuangan Nomor 19/POJK.03/2014 Tentang Layanan Keuangan Tanpa Kantor Dalam Rangka Keuangan Inklusif :

1. Hak dan kewajiban Bank penyelenggara Laku Pandai dan Agen;

2. Ruang lingkup layanan yang dapat disediakan Agen;
3. Penetapan wilayah kerja operasional Agen;

4. Penetapan klasifikasi Agen;

5. Jangka waktu pelaksanaan kerjasama dan mekanisme perpanjangannya;

6. Mekanisme dan hubungan kerja antara Bank dan Agen;

7. Syarat dan tata cara perubahan perjanjian kerjasama;

8. Penetapan sanksi dan mekanisme pengenaan sanksi;

9. Kondisi dan tata cara penghentian perjanjian kerjasama; dan

10. Tata cara penyelesaian perselisihan

Dampak dari kemajuan tehnologi perbankan saat ini dimungkinkan sekali antar bank terjadi pertukaran informasi atas data nasabah. Apabila nasabah merasa dirugikan akibat terbukanya keterangan tentang data dirinya dan simpanannya, maka nasabah berhak mengetahui isi keterangan tersebut dan meminta pembetulan apabila terdapat kesalahan, tetapi apabila pihak nasabah tetap merasa dirugikan maka dapat mengajukan permasalahan tersebut kepada pengadilan setempat, karena kepentingan nasabah atas simpanannya mendapat perlindungan hukum sebagaimana termuat dalam Pasal 45 Undang-Undang Nomor 10 Tahun 1998 tentang Perubahan Undang-Undang Nomor 7 Tahun 1992 tentang Perbankan. 
Priadhi Harry Ramdhany, Hubungan Hukum Antara Bank Dengan Agen Laku Pandai (Branchless...

Abdul Kadir Muhamad mengemukakan tentang teori tanggung jawab dalam perbuatan hukum atau tort liability dibagi menjadi 3 teori, yaitu :

1. "Tanggung jawab akibat perbuatan melanggar hukum yang dilakukan dengan sengaja (intertional tort liability), tergugat harus sudah melakukan perbuatan sedemikian rupa sehingga merugikan penggugat atau mengetahui bahwa apa yang dilakukan tergugat akan mengakibatkan kerugian.

2. Tanggung jawab akibat perbuatan melanggar hukum yang dilakukan karena kelalaian (negligence tort lilability), didasarkan pada konsep kesalahan (concept of fault) yang berkaitan dengan moral dan hukum yang sudah bercampur baur (interminglend).

3. Tanggung jawab mutlak akibat perbuatan melanggar hukum tanpa mempersoalkan kesalahan (stirck liability), didasarkan pada perbuatannya baik secara sengaja maupun tidak sengaja, artinya meskipun bukan kesalahannya tetap bertanggung jawab atas kerugian yang timbul akibat perbuatannya" (ABDULKADIR MUHAMMAD 2010:503)
Pengertian pertanggungjawaban menurut Titik Triwulan adalah bahwa "pertanggungjawaban harus mempunyai dasar, yaitu hal yang menyebabkan timbulnya hak hukum bagi seorang untuk menuntut orang lain sekaligus berupa hal yang melahirkan kewajiban hukum orang lain untuk memberi pertanggungjawabannya”. Berdasarkan hukum perdata, pertanggung jawaban terdiri dari unsur kesalahan dan resiko, yang biasa disebut liabilty without based on fault (tanggung jawab karena adanya kesalahan) dan liabilty without fault (tanggung jawab tanpa ada kesalahan) yang biasa disebut dengan strick liabiliy (tanggung jawab mutlak atau resiko). Liabilty without based on fault (tanggung jawab karena adanya kesalahan) adalah pertanggung jawaban seseorang karena kesalahan yang dilakukannya sehingga mengakibatkan kerugian pada pihak lain atau orang lain, sedangkan liabilty without fault (tanggung jawab tanpa ada kesalahan) yang biasa disebut dengan strick liabiliy (tanggung jawab mutlak atau resiko) adalah bahwa seseorang harus bertanggung jawab atas segala resiko yang terjadi sehubungan dengan usaha yang dilakukannya (TITIK TRIWULAN DAN SHINTA FEBRIAN 2010:48)

Berdasarkan Undang-Undang Nomor 10 Tahun 1998 tentang Perubahan 
Priadhi Harry Ramdhany, Hubungan Hukum Antara Bank Dengan Agen Laku Pandai (Branchless...

Undang-Undang Nomor 7 Tahun 1992 tentang Perbankan terutama pada pasal 29 ayat (4) menyebutkan : "Untuk kepentingan nasabah, bank wajib menyediakan informasi mengenai kemungkinan timbulnya risiko kerugian sehubungan dengan transaksi nasabah yang dilakukan melalui bank", sedangkan dalam peraturan Otoritas Jasa Keuangan Nomor 1/POJK.07/2013 tentang Perlindungan Konsumen Sektor Jasa Keuangan terutama pada pasal 4 ayat (1) dan (2) menentukan bahwa:

1. Ayat (1) : "Pelaku Usaha Jasa Keuangan wajib menyediakan dan/atau menyampaikan informasi mengenai produk dan/atau layanan yang akurat, jujur, jelas, dan tidak menyesatkan".

2. Ayat (2) : "Informasi sebagaimana dimaksud pada ayat (1) dituangkan dalam dokumen atau sarana lain yang dapat digunakan sebagai alat bukti”.

Ketentuan tersebut sangat terlihat bahwa bank wajib memberikan informasi secara terbuka dan jelas terhadap segala resiko yang timbul akibat transaksi yang dilakukan oleh nasabah. Informasi ini harus disosialisasikan pada masyarakat dalam hal ini nasabah, agen dan bank agar apabila terjadi hal-hal yang tidak diinginkan akibat dari adanya transaksi keuangan produk perbankan maka para pihak dapat langsung meminta pertanggung jawaban kepada pihak yang melakukan kesalahan atau fraud dan/atau wanprestasi

\section{PENUTUP}

\section{Simpulan}

a. Agen bukanlah pihak termaksud dalam pasal 46 dalam UndangUndang Nomor 10 Tahun 1998 tentang Perubahan UndangUndang Nomor 7 Tahun 1992 tentang Perbankan, walaupun dalam kenyataannya agen memang menjalankan usaha dalam melakukan penghimpunan dana dari masyarakat. Agen bukan pula sebagai pegawai bank sebagaimana yang dimaksud dalam penjelasan pasal 47 ayat (2) Undang-Undang Nomor 10 Tahun 1998 tentang Perubahan Undang-Undang Nomor 7 Tahun 1992 tentang Perbankan. Agen merupakan kepanjangan tangan dari Bank yang menyelenggarakan layanan branchless banking untuk memberikan layanan keuangan pada masyarakat sebagaimana dimaksud dalam pasal 1 ayat (1) Peraturan Otoritas Jasa Keuangan Nomor 19/POJK.03/2014 tentang 
Priadhi Harry Ramdhany, Hubungan Hukum Antara Bank Dengan Agen Laku Pandai (Branchless...

Layanan Keuangan Tanpa Kantor Dalam Rangka Keuangan Inklusif.

b. Peraturan Otoritas Jasa Keuangan Nomor 19/POJK.03/2014 tentang Layanan Keuangan Tanpa Kantor Dalam Rangka Keuangan Inklusif yang belum mengatur dengan jelas terutama tentang kewajiban agen dalam memberikan perlindungan kepada nasabah yaitu kewajiban dalam melindungi nasabah penyimpan dan simpanannya, maka dapat menimbulkan masalah dikemudian hari terutama dalam hal siapa yang harus bertanggungjawab apabila terjadi tuntutan dari nasabah atas terbukanya data dan simpanannya, karena bisa saja, agen mengelak atau menolak untuk bertanggung jawab apabila nasabah melakukan tuntutan kepadanya, dan akhirnya melemparkan kesalahan ini kepada pihak Bank Laku Pandai. Bank Laku Pandai dan agen harus secara bersama-sama bertanggung jawab terhadap pekerjaannya dalam hal ini terutama apabila terjadi terbukanya data nasabah penyimpan dan simpanannya yang mengakibatkan suatu kelalaian berupa cedera janji atau wanprestasi, merujuk pada ketentuan yang terdapat dalam Pasal 1365, 1366 dan 1367 Kitab Undang-Undang Hukum Perdata dan Pasal 323 Kitab UndangUndang Hukum Pidana.

\section{Saran}

a. implementasi aturan hukum dari prinsip kehati-hatian (prudential principle) sebagaimana dalam Pasal 2 UU No. 10 Tahun 1998 tentang Perbankan pada Branchless Banking (layanan keuangan tanpa kantor) adalah penerapan Customer due diligence (CDD) kepada calon nasabah. Prosedur Customer due diligence $(C D D)$ ini digunakan bank untuk calon nasabah yang akan membuka rekening dan setiap saat dapat dilakukan apabila ada perubahan tentang data atau profil nasabah. Apabila diperlukan calon nasabah harus dapat menunjukkan bukti-bukti pendukung asal dan penggunaan dana yang disimpan di Bank proses tersebut biasa disebut dengan Enhanced Due Diligence $(E D D)$ atau uji tuntas lanjut. Prosedur Customer due diligence $(C D D)$ ini dilakukan bertujuan agar tercipta industri keuangan yang bebas dari tindak 
Priadhi Harry Ramdhany, Hubungan Hukum Antara Bank Dengan Agen Laku Pandai (Branchless...

pidana pencucian uang dan pendanaan terorisme.

b. Sebagaimana dana yang dikelola oleh Bank sebagian besar merupakan dana dari masyarakat yang mempercayakan sebagian besar dananya untuk disimpan di Bank, maka sudah seharusnya bank menjaga dana tersebut supaya tidak terjadi kebocoran rahasia jumlah maupun identitas nasabah yang diketahui oleh pihak-pihak yang tidak berkepentingan (pihak yang secara resmi mempunyai kewenangan/ditunjuk oleh bank yang bersangkutan melalui perjanjian atau undang-undang), kecuali Undang-Undang menyatakan sebaliknya.Dalam hal terjadinya kebocoran jumlah maupun identitas nasabah tentunya akan berakibat pada resiko yang tinggi terhadap terjadinya tindak pidana seperti; penggelapan, pencurian, maupun penipuan mengenai hak dan kewajiban nasabah sesuai yang diperjanjikan dalam hal layanan atau produk-produk kegiatan usaha bank.Oleh karena itu perlindungan hukum harus dititikberatkan pada nasabah daripada agen sebagai penyelenggara laku pandai yang memiliki kewenangan menurut Peraturan Otoritas Jasa Keuangan Nomor 19/POJK.03/2014 tentang Layanan Keuangan Tanpa Kantor Dalam Rangka Keuangan Inklusif. Sehinnga asas Ultimum Remidium (upaya terakhir) dalam Hukum Pidana dapat dikesampingkan.

\section{DAFTAR PUSTAKA}

\section{Buku-Buku :}

Abdul Ghofur Anshori, Pembentukan Bank Syariah Melalui Akuisisi dan Konversi (Pendekatan Hukum Positif dan Hukum Islam), Yogyakarta, UII Press, 2001

Abdul Ghoruf Anshori, "Hukum Perbankan Syariah”, UU No. 21 Tahun 2008, Refika Aditama, Bandung, 2009

Abdulkadir Muhammad, "Hukum Perusahaan Indonesia”, Citra Aditya Bakti, 2010

Abdulkadir Muhammad, "Lembaga Keuangan dan Pembiayaan”, Bandung: Citra Aditya Bhakti, 2004 Achmad Deni Daruri, "Bunga Rampai Sistem Pembayaran", Center for 
Priadhi Harry Ramdhany, Hubungan Hukum Antara Bank Dengan Agen Laku Pandai (Branchless...

Banking Crisis, Cetakan Pertama, Oktober 2103

Adrian sutedi, "Hukum Perbankan Suatu tinjauan Pencucian Uang, Merger, Likuidasi, dan Kepailitan” PT Sinar Grafika, Maret, 2010

Adrian Sutedi, S.H.,M.H. "Aspek Hukum Otoritas Jasa Keuangan, Raih Asa Sukses” (Penebar Swadaya Grup), Cet I, Jakarta 2014

Adriana Elisabeth, "Kecenderungan dan Tantangan Globalisasi Ekonomi terhadap Politik Luar Negeri Indonesia”, dalam Ganewati Wuryandari (ed.), Perkembangan Politik Internasional dan Pengaruhnya terhadap Politik Luar Negeri Indonesia, Jakarta, LIPI, Press 2008

C.s.t. Kansil, "Modul Hukum Perdata Termasuk Asas-Asas Hukum Perdata”, Pradnya Paramita, Jakarta, 2006

CST Kansil dan Christine ST Kansil, "Pokok-pokok Pengetahuan Hukum Dagang Indonesia”, Sinar Grafika, Jakarta, 2002

Djamali, R. Abdoel,"Pengantar Hukum Indonesia”, PT Raja Grafindo Persada, Jakarta, 2005

Edi Hudiata, "Penyelesaian Sengketa Perbankan Syariah:Pasca Putusan MK Nomor 93/PUU-X/2012:Litigasi dan Non Litigasi”, UII Press, Yogyakarta, 2015

Elly Erawati dan Herlien Budiono, "Penjelasan Hukum tentang Kebatalan Perjanjian”, PT. Alumni, Bandung, 2001

Hafidhuddin, Didin dan Hendri Tanjung, "Manajemen Syariah dalam Praktek”, tc., Jakarta: Gema Insani Press, 2003

Haroen, Nasrun, "Fiqih Muamalah", Jakarta: Gaya Media Pratama, cet. 1, 2000

Herlien Budiono, “Ajaran Umum Hukum Perjanjian dan Penerapannya di Bidang Kenotariatan”, Citra Aditya Bakti, Bandung, 2011

Hermansyah (Edisi Revisi), "Hukum Perbankan Nasional Indonesia Ditinjau Menurut Undang-Undang No. 7 Tahun 1992 Tentang Perbankan sebagaimana telah diubah dengan Undang-Undang No. 10 Tahun 1998, dan UndangUndang No. 23 Tahun 1999 jo. Undang-Undang No.3 Tahun 2004 tentang Bank Indonesia”, Jakarta: Kencana Prenada Media Group, 2005

Hermansyah, "Hukum Perbankan

Nasional Indonesia”, Kencana Prenada Media Group 2007, Jakarta 
Priadhi Harry Ramdhany, Hubungan Hukum Antara Bank Dengan Agen Laku Pandai (Branchless...

Khatibul Umam, "Legislasi Fikih Ekonomi dan Penerapannya Dalam Produk Perbankan Syariah Di Indonesia”, Yogyakarta, BPEF, 2011

Mujahidin Akhmad, "Hukum Perbankan Syariah”, Jakarta, Cet. 1, Ed. 1, Rajawali Pers, 2016

Naoyuki Yoshino, Peter J Morgan, "Keuangan Inklusi, Regulasi, dan Edukasi” (terjemahan judul buku "Financial Inclusion, Regulation, and Education”), ASIAN Development Bank Institute, 2017

Neni Sri Imaniyati, "Perbankan Syariah dalam Perspektif Hukum Ekonomi”, Mandar Maju, Bandung, 2013

Neni Sri Imaniyati, dan Panji Adam Agus Putra," Pengantar Hukum Perbankan Indonesia”, PT Refika Aditama, Cet 2(dua), Bandung, November 2016

Neni Sri Imaniyati, Hukum Bisnis: "Telaah tentang pelaku dan kegiatan ekonomi", Graha Ilmu Yogyakarta, 2009

Padmo Wahjono, “Indonesia Negara Berdasarkan atas Hukum”, (Jakarta Ghalia Indonesia, 1986), Cet. II

Paul Scholten di dalam JJ.H Bruggink, "Refleksi Tentang Hukum", (alih bahasa oleh Arief Sidharta), Cipta Aditya Bhakti, Bandung 1996
Rachmadi Usman, "Hukum Ekonomi Dalam Dinamika”, Jakarta, Djembatan, 2000

Rakhmindyarto dan Syaifullah dalam Bunga Rampai "Pemikiran Ekonomi Hijau dan Keuangan Inklusif”, Bale Siasat, 2013

Richard Burton Simatupang, "Aspek Hukum dalam Bisnis”, Rineka Cipta, Jakarta, 2003

Sentosa Sembiring, "Hukum Perbankan", Bandung, Bandar Maju, 2012

Soerjono Soekanto, "Pengantar Penelitian Hukum”, Jakarta, UI Press, 2008

Subekti, “Hukum Perjanjian”, Intermasa, Bandung 2002

Sutan Remy Sjahdeini, “Kebebasan berkontrak dan Perlindungan Yang Seimbang Bagi para pihak dalam Perjanjian Kredit Bank di Indonesia", Jakarta: Intitusi Bankir Indonesia, 1993

Syamsul Anwar, "Hukum Perjanjian Syariah Studi tentang Teori Akad dalam Fikih Muamalah", Jakarta, Rajawali Pers, cet. Ke-2, 2010

Titik Triwulan dan Shinta Febrian, "Perlindungan Hukum bagi Pasien”, Prestasi Pustaka, Jakarta, 2010

Titik Triwulan Tutik, "Hukum Perdata Dalam Sistem Hukum Nasional", Prenada Media Group, Jakarta, 2008 
Totok Budisantoso dan Sigit Triandaru,

"Bank dan Lembaga Keuangan Lain”, Edisi 2, Salemba Empat, Jakarta, 2006

Uswatun Hassanah, S.H.,M.Hum. "Hukum Perbankan”, Setara Press, Malang, jawa Timur, Februari 2017

Wahbah Az-Zuhaili, "Fiqih Islam Wa Adillatuhu”, Gema Insani,Jakarta, Jilid 4, Cetakan I, 2011

Zainuddin Ali, "Metode Penelitian Hukum”, Jakarta, Sinar Grafika, 2013

Zulkarnain Sitompul, "Lembaga Penjamin Simpanan, Substansi dan Permasalahan", Bandung, Books Terrace \& Library, 2007

\section{Disertasi, Tesis, dan Makalah}

Muliaman

D. Hadad, Ketua Dewan Komisioner OJK, "Financial Technology (Fin Tech) di Indonesia”, Kuliah Umum tentang FinTech-IBS, Jakarta, 2 Juni 2017

Syamsyul Hadi, dkk, "Strategi Pembangunan Indonesia Pasca IMF”, Hasil Penelitian Syamsyul Hadi, dkk, CIReS, 2004

Tim Kerjasama Penelitian FEB UGM \& FE UI, Alternatif Struktur OJK Yang Optimum, Kajian Akademik, 23 Agustus 2010
Yulius P Hermawan, Proyek Riset G-20, "Peran Indonesia Dalam G20:Latar Belakang, Peran, dan Tujuan Keanggotaan Indonesia”, Friedrich-Ebert-Stiftung Indonesia Office (Kantor Perwakilan Indonesia bekerja sama dengan Departemen Hubungan Internasional Universitas Parahyangan), Cet I Mei 2011 Jakarta Selatan

Zaidatul amina, "Kajian Pembentukan Otoritas Jasa Keuangan Di Indonesia:Melihat Dari Pengalaman Di Negara Lain”, Universitas Negeri Surabaya, 2012

Zaidatul amina, "Kajian Pembentukan Otoritas Jasa Keuangan Di Indonesia:Melihat Dari Pengalaman Di Negara Lain”, Universitas Negeri Surabaya, 2012

\section{Kamus dan Ensiklopedi :}

Bryan.A.Garner, "Blacks Law Dictionary”, Eight Edition, West Publishing Co, St. Paul-Minn, 2004 Departemen Pengembangan Akses Keuangan dan UMKM Bank Indonesia (2014), “Keuangan Inklusif", Sumber informasi dari, "National Strategy for Financial Inclusion Fostering Economic Growth and Accelerating Poverty Reduction", (Sekertariat 
Priadhi Harry Ramdhany, Hubungan Hukum Antara Bank Dengan Agen Laku Pandai (Branchless...

Wakil Presiden Republik Indonesia-

Juni 2012)

Pungky Purnomo Wibowo, "Branchless

Banking

Setelah

Multilicense:Ancaman

atau

Kesempatan Bagi Perbankan

Nasional”, Staff Pimpinan Bank

Indonesia (SESPIBI) Angkatan

XXXI

\section{Jurnal, Artikel, dan Situs Internet :}

Abdul Mughits, "Kompilasi Hukum Ekonomi Syariah (KHES) Dalam Tinjauan Hukum Islam”, dalam Jurnal Al-Mawarid Edisi XVIII tahun 2008

Abu Samman Lubis ,Memahami Peran Lembaga Penjamin Simpanan sebagai Jaring Pengaman Sistem Perbankan Nasional,

http://www.bppk.depkeu.go.id>, diunduh pada hari Sabtu Tanggal 21 April 2018 Pukul 20.00 Wib

Satjipto Rahardjo, "Membangun Hukum yang Diarahkan pada Kepada Tujuan Nasional", Artikel pada Majalah Masalah-masalah Hukum, FH UNDIP Semarang, No. 5 Tahun XII, 1982

www.bi.go.id (data dari CGAP dan World Bank, diunduh dari situs resmi Bank
Indonesia pada hari selasa, 3 Januari 2018, pukul 15:30 Wib)

www.btpn.com (diunduh dari situs resmi Bank BTPN pada hari selasa, 3 Januari 2018, pukul 15:33 Wib)

$\underline{w w w . i n d o t e l k o m . c o m}$ (diunduh dari situs resmi telkomsel pada hari rabu, 4 Januari 2018, pukul 10:31 Wib www.worldbank.org (diunduh dari situs resmi Bank Dunia pada hari Selasa, 13 Maret 2018, pukul 11.30 Wib).

www.bi.go.id (diunduh dari situs resmi Bank Indonesia pada hari Selasa, 13 Maret 2018, pukul 12.50 Wib). www.tribunnews.com/BTPN Wow! Desa Ciampea Kota Bogor, diunduh pada hari Sabtu tanggal 21 April 2018, pada pukul $16.00 \mathrm{Wib}$

www.imf.org pada "International Financial Statistics” (IMF 2011), (data dari IMF, diunduh dari situs resmi IMF pada hari selasa, 13 Maret 2018, pukul 15:30 Wib)

Zulkarnain Sitompul, "Menyambut Kehadiran Otoritas Jasa Keuangan (OJK)”, Pilars No. 02/Th.VII/12-18 Januari 2004

\section{Peraturan Perundang-Undangan}

Undang-Undang Dasar Negara Republik Indonesia Tahun 1945 
Priadhi Harry Ramdhany, Hubungan Hukum Antara Bank Dengan Agen Laku Pandai (Branchless...

Undang-Undang No. 10 Tahun 1998 tentang Perbankan

Peraturan Otoritas Jasa Keuangan No. 19/POJK.03/2014 tentang Layanan Keuangan Tanpa Kantor Dalam Rangka Keuangan Inklusif

Kitab Undang-Undang Hukum Perdata

\section{Sumber Lain :}

Data Berupa Laporan Tahunan Bank BTPN Wow! :

Data Pertumbuhan Pembiayaan BTPN Syariah Di Tahun 2015

Achmad Nusjirwan Sugondo, "Sinergi Pandai Demi Laku Pandai”, Anggota Asosiasi FinTech Indonesia dan Product\&Costumer Experience Head BTPN Wow!, Indonesia Communications (ID COMM)

Laporan Tahunan BTPN Syariah, ”Tumbuh Untuk Keuangan Inklusif", Bank BTPN Syariah Tahun 2015

Laporan Tahunan BTPN,"'Langkah Maju

Untuk Merevolusi Dunia Perbankan", banking reinvented, PT BTPN tahun 2016

Direktorat Penelitian dan Pengaturan Perbankan, "Penerapan Branchless Banking di Indonesia”, Jakarta;Bank Indonesia, 2011

Laporan Hasil Kajian Kementerian Keuangan Republik Indonesia, "Liberisasi Jasa Keuangan
Indonesia Dalam Perundingan Liberisasi Jasa Keuangan”, Pusat Kebijakan Regional dan Bilateral Badan Kebijakan Fiskal Kementrian Keuangan

Departemen Pengembangan Akses Keuangan dan UMKM Bank Indonesia (2014), “Keuangan Inklusif", Sumber informasi dari, "National Strategy for Financial Inclusion Fostering Economic Growth and Accelerating Poverty Reduction", (Sekertariat Wakil Presiden Republik IndonesiaJuni 2012) dan penyesuaian hasil pembahasan Kementrian/Instansi terkait

Miranda Gultom, Sambutan Deputi Gubernur Senior Bank Indonesia pada seminar "Strategi Pengembangan Lembaga Keuangan Syariah di Indonesia”, Jakarta: BI, 15 September 2005.

\section{Berupa Wawancara Terkait Dengan Penelitian}

Wawancara terhadap Bapak Achmad Nusjirwan Sugondo selaku anggota Asosiasi FinTech Indonesia dan Product\&Costumer Experience Head BTPN Wow! di Desa Ciampea Kota Bogor pada hari Jumat 20 April 2018, pukul 10.00Wib 
Priadhi Harry Ramdhany, Hubungan Hukum Antara Bank Dengan Agen Laku Pandai (Branchless...

Berdasarkan hasil wawancara dengan wakil direktur sub bag Branchless Banking Bank BTPN Bapak Hadi Wibowo pada hari Kamis tanggal 12 April Tahun 2018 Pukul 14.00Wib di Menara BTPN - CBD Mega Kuningan Jl.Dr. IdeAnak Agung GdeAgung Kav5.5-5.6 Jakarta 12950 